\title{
KASTELUVESIEN LAATU OSANA TUOREKASVISTEN TUOTETURVALLISUUTTA
}

\author{
Tuominen Riina ${ }^{1)}$, Marjatta Lehesvaara ${ }^{2)}$, Soininen Hanne ${ }^{2)}$ ja Sari Seppäläinen ${ }^{2)}$ \\ ${ }^{1)}$ Helsingin yliopisto, Ruralia-instituutti, Lönnrotinkatu 7, 50100 Mikkeli, riina.sh.tuominen@helsinki.fi \\ ${ }^{2)}$ Mikkelin ammattikorkeakoulu, PL 181, 50101 Mikkeli, etunimi.sukunimi@mamk.fi
}

\section{TIIVISTELMÄ}

TuoPro-Tuorekasvisten turvallisuuden parantaminen-hankkeessa on Helsingin yliopiston Ruraliainstituutissa ja Mikkelin ammattikorkeakoulussa vuosina 2012 - 2013 tarkasteltu kasteluvesien laatua osana tuorekasvisten tuoteturvallisuutta. Hanketta rahoittaa Hämeen ELY-keskus Euroopan maaseudun kehittämisen maatalousrahastosta.

Alkutuotantoasetus eli Maa- ja metsätalousministeriön asetus 1368/2011 elintarvikkeiden alkutuotannon elintarvikehygieniasta velvoittaa niitä viljelijöitä, joilla kasteluvesi päätyy suoraan kasvin syötävien osien pinnoille, tutkituttamaan kasteluveden laadun laboratoriossa vähintään kolmen vuoden välein. Tämä tutkimusvelvoite koskee myös niitä toimijoita, jotka käyttävät vettä tuotteiden pesuun ja jäähdytykseen.

Hankkeessa on arvioitu kasteluvesilähteiden riskejä ja tähän mennessä analysoitu noin 80 vesinäytettä. Vesilähteitä ovat olleet muun muassa luonnon vesilähteet ja niistä kaivetut kasteluojastot, kaivot ja vesilaitoksen jakama vesi. Näytteistä on Mikkelin ammattikorkeakoulun ympäristölaboratoriossa määritetty koliformiset bakteerit, E.coli ja suolistoperäiset enterokokit. Suurin osa tutkituista näytteistä on täyttänyt alkutuotantoasetuksen mukaiset vaatimukset. Kasteluveden laatu on merkittävässä osassa ajatellen kasvisten mikrobiologista tuoteturvallisuutta ja edelleen toiminnan kannattavuutta.

Asiasanat: alkutuotanto, alkutuotantoasetus, kasvikset, tuoteturvallisuus, kasteluvesi, mikrobiologinen laatu 


\section{Johdanto}

TuoPro-Tuorekasvisten turvallisuuden parantaminen-hankkeessa on Helsingin yliopiston Ruraliainstituutissa ja Mikkelin ammattikorkeakoulussa vuosina 2012 - 2013 tarkasteltu kasteluvesien laatua osana tuorekasvisten tuoteturvallisuutta. Hanketta rahoittaa Hämeen ELY-keskus Euroopan maaseudun kehittämisen maatalousrahastosta.

Viljelysten kasteluun käytetään yleisesti pintavettä ja veden laadulla on suuri merkitys myös tuotteiden laatuun. Pintaveden laatuun vaikuttavat mm. vesistön luontainen ominaispiirre, hajakuormitus, veden virtaavuus ja säätila. Jokiveden laatu voi vaihdella jopa päivittäin, riippuen siitä, mitä joen yläjuoksulla on. Veden laatu vaihtelee myös vuodenaikojen mukaan, keväällä ja syksyllä laatu voi heiketä sulamisvesien ja valumavesien vuoksi ja kesällä levät saattavat heikentää paikallisesti pintaveden käyttökelpoisuutta. Pintavedet saastuvat herkästi, sillä niillä ei ole suojaa saasteita vastaan, toisin kuin pohjavesillä.

Kasvikset vaativat kastelua varsinkin kuivina kesinä. Kasteluvesi on merkittävässä asemassa kasvisten turvallisuuden suhteen, ja siksi kasteluveden täytyy täyttää sille asetetut vaatimukset. Alkutuotantoasetuksen (134/2006) mukaan kasteluvesi tulee tutkituttaa, kun kastellaan sellaisenaan syötäviä kasvien osia ja vesi päätyy syötävään osaan, esim. sadetuskastelu suoraan salaatille tai marjoille. Kasteluun saa käyttää vain sellaista vettä, josta on tutkittu vähintään Escherichia coli ja suolistoperäiset enterokokit sekä arvioitu aistinvarainen väri ja haju sekä, kun on kysymys luonnon pintavesistä, syanobakteerien esiintyminen. Tutkimuksia ei vaadita, jos kastelu tapahtuu altakasteluna, jolloin vesi ei ole kosketuksissa syötäviin osiin, tai jos kastelu tapahtuu sadetuksena vain kukintoaikana esim. hallantorjuntaan.

Tutkimukset on tehtävä vähintään kolmen vuoden välein sellaisesta näytteestä, joka edustaa kasteluun käytettävää vettä. Näytteet on tutkittava hyväksytyssä omavalvontalaboratoriossa, viranomaisnäytteitä tutkimaan hyväksytyssä laboratoriossa tai kansallisessa vertailulaboratoriossa. Jos vedessä todetaan Escherichia coli -bakteereita yli 300 pmy/100 ml, suolistoperäisiä enterokokkeja yli 200 pmy/100 ml, poikkeavaa väriä tai hajua tai syanobakteerien massaesiintymä, toimijan on ryhdyttävä toimenpiteisiin veden laadun parantamiseksi. (Alkutuotantoasetus 134/2006.)

Kemiallisten muuttujien osalta veden laadun arvioinnissa noudatetaan pienten yksiköiden talousveden laatuvaatimuksista ja valvontatutkimuksista annetun sosiaali- ja terveysministeriön asetuksen (401/2001) 1 §:n 3 kohdassa tarkoitetulle vedelle asetettuja laatuvaatimuksia ja -suosituksia.

\section{Aineisto ja menetelmät}

Kasteluvesinäytteitä otettiin Etelä-Savon alueelta 72 kappaletta touko-kesäkuussa 2013. Vesilähteitä olivat muun muassa luonnon vesilähteet ja niistä kaivetut kasteluojastot, kaivot ja vesilaitoksen jakama vesi. Kuvassa 1 on esitetty kasteluvesilähteet.

Kasteluvesinäytteet pyrittiin ottamaan sellaisesta kohdasta, joka kuvaa mahdollisimman edustavasti kasville päätyvää vettä. Näytteet otettiin standardin SFS-EN ISO 19458 mukaan ja toimitettiin analysoitavaksi Mikkelin ammattikorkeakoulun ympäristölaboratorioon näytteenottopäivänä. Näytteet otettiin $250 \mathrm{ml}: \mathrm{n}$ steriileihin polypropeenista valmistettuihin muovipulloihin. Näytteenoton puhtaus varmistettiin huolehtimalla käsihygieniasta ja suojaamalla näyte ilmavirralta, roiskeilta ja muulta likaantumiselta. Pulloon jätettiin hieman ilmatilaa, jotta näytettä pystyi sekoittamaan. Pullo suljettiin välittömästi näytteenoton jälkeen. Näytteet pakattiin kylmäpatruunoilla varustettuun kylmälaukkuun ja kuljetettiin laboratorioon. Laboratoriossa näytteet säilytettiin pimeässä ja viileässä yön yli ja analysointi aloitettiin seuraavana aamuna.

Koliformiset bakteerit ja E.Coli määritettiin Colilert-menetelmällä. Suolistoperäiset enterokokit eristettiin kalvosuodatusmenetelmällä SFS-EN ISO 8199 -standardin mukaisesti ja analysoitiin SFS-EN ISO 7899-2 -standardin mukaan. 


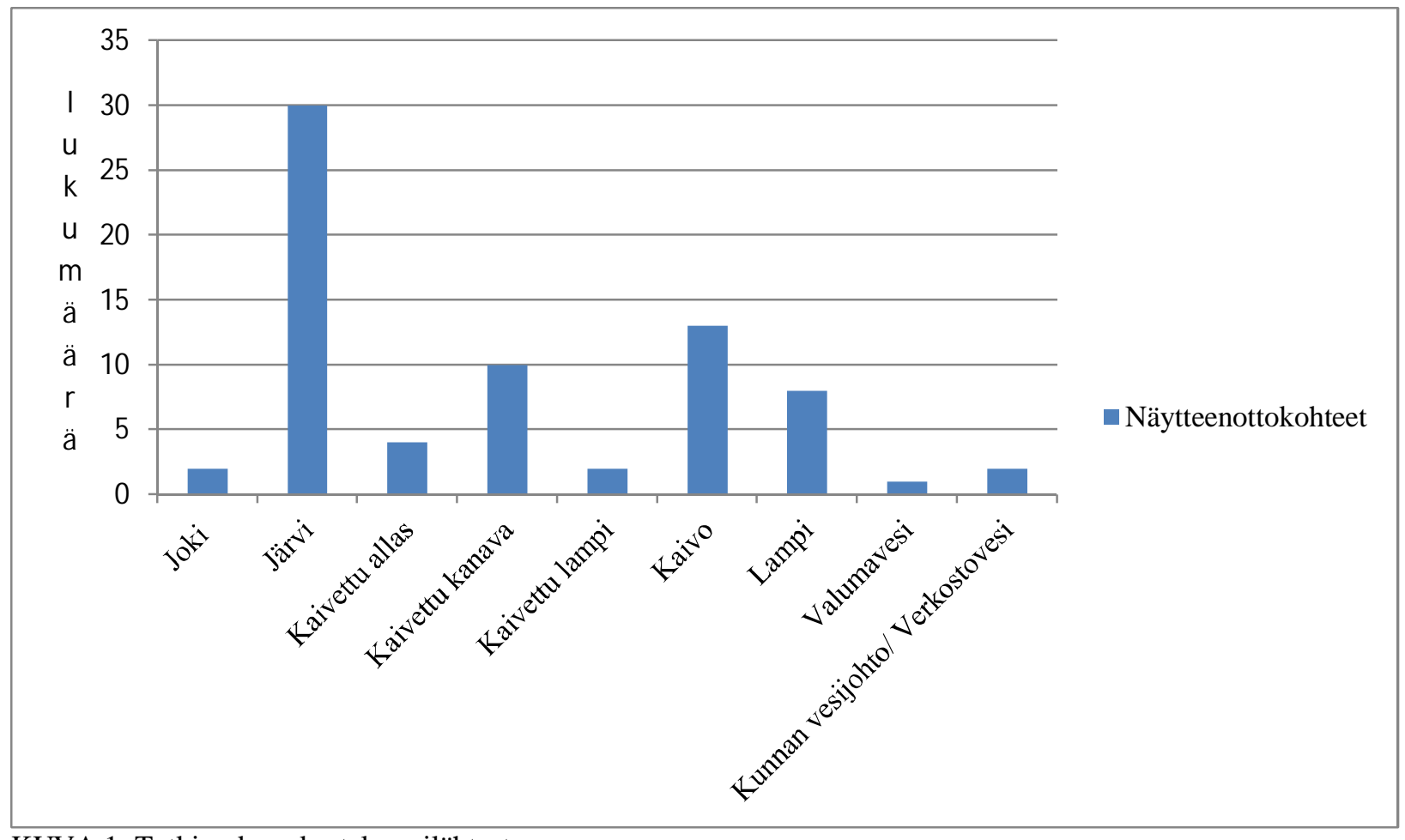

KUVA 1. Tutkimuksen kasteluvesilähteet

\section{Tulokset ja tulosten tarkastelu}

Kasteluvesinäytteiden tulosten tulkinta perustuu alkutuotantoasetuksen määräämiin raja-arvoihin.

Analysoitujen näytteiden suolistoperäisten enterokokkien tulokset olivat yhtä tulosta lukuun ottamatta asetuksen mukaisia eli alle 200 pmy/100 ml. Kuvassa 2 on esitetty raja-arvon alittavien tulosten jakautuminen. Escherichia colin osalta tulokset olivat raja-arvon alapuolella (300 pmy/100 ml).

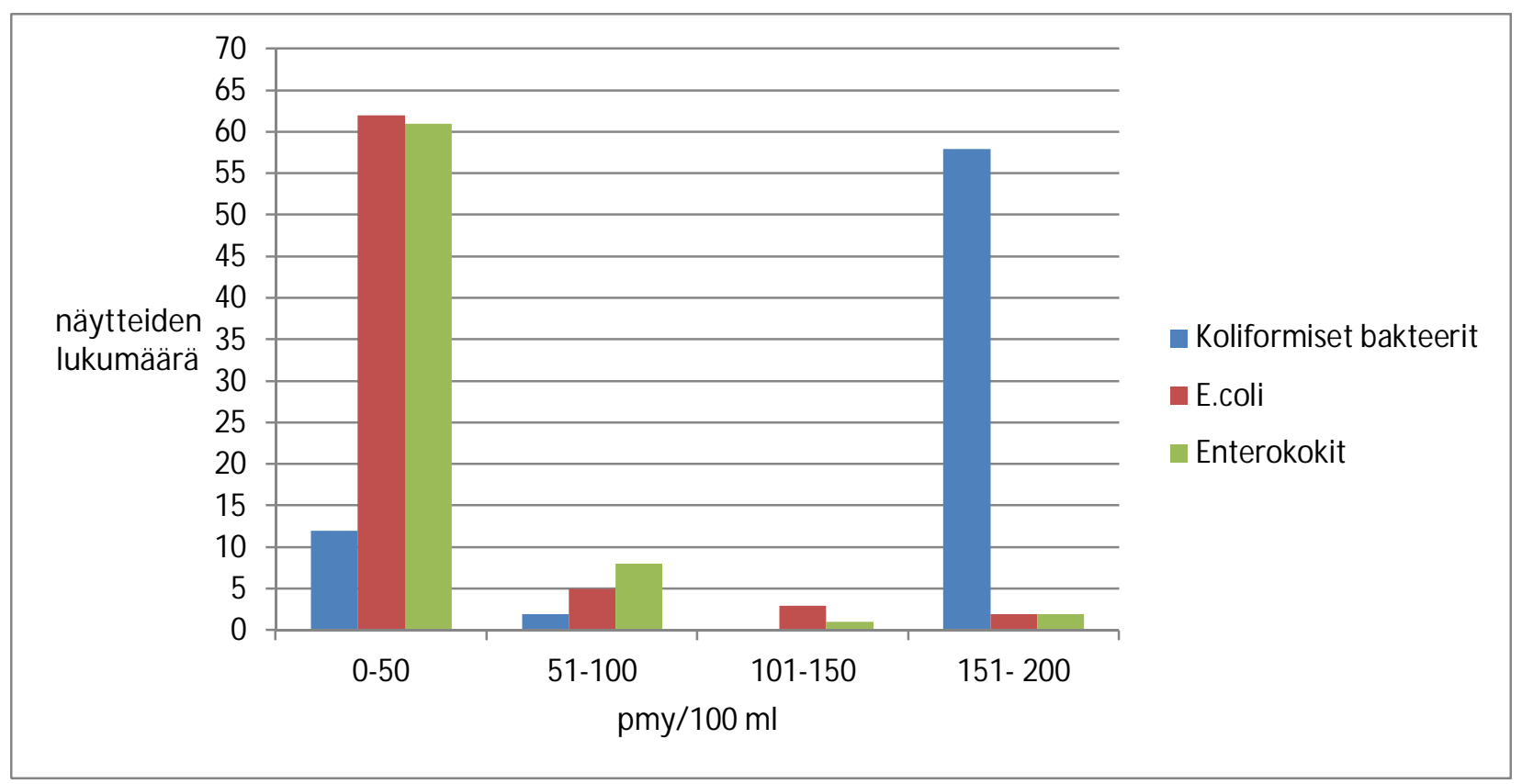

KUVA 2. Analysoitujen kasteluvesinäytteiden tulokset 


\section{Johtopäätökset}

Kasteluvesinäytteiden analyysitulokset vastasivat yhtä näytettä lukuun ottamatta alkutuotantoasetuksen vaatimuksia. Kuitenkin kohteissa, joissa tutkittuja mikrobeja esiintyy kohonneita määriä, kannattaa kiinnittää huomiota kasteluvesilähteiden rakenteisiin ja muihin veden laatuun vaikuttaviin tekijöihin.

Kasteluvesinäytettä ei ollut aina mahdollista ottaa kastelulaitteesta, jolloin sen vaikutus veden laatuun jäi huomioimatta. Kastelulaitteistoiden pitkissä putkissa seisovassa vedessä mikrobien on mahdollista lisääntyä ja suositeltavaa onkin ruiskuttaa laitteistossa seisonut vesi muualle kuin kasvustoon.

Yksittäinen näyte ei muutoinkaan anna luotettavaa kuvaa kasteluveden laadusta, sillä veden laatu voi vaihdella suurestikin varsinkin virtaavissa lähteissä. Veden laadun arvioimiseksi ja näytteenoton kohdentamiseksi oikea-aikaiseksi voidaan apuna käyttää kasteluveden riskinarviointia. Riskinarvioinnissa tunnistetaan kaikki mahdolliset vesilähdettä uhkaavat vaarat sekä arvioidaan vaarojen vaikutukset ja todennäköisyydet.

Kasteluveden ominaisuudet voivat vaikuttaa kasviksiin ja vaarat voivat siirtyä myös kuluttajalle, varsinkin jos kastelu tapahtuu lähellä sadonkorjuuta. Alkutuotantoasetuksen säätämä vesinäytteiden tutkimusväli on kasteluveden laadun toteamiseksi melko pitkä, ja asetuksessa vaaditut analyysit ovat melko suppeat verrattaessa niitä mahdollisiin vaaroihin. Määritettävät parametrit ja niiden analysointiväli perustuvat kuitenkin riskinarviointiin. Viljelijän on kuitenkin hyvä tehdä kastevedestä aistinvarainen arviointi aina ennen kastelua.

\section{Kirjallisuus}

MMM:n alkutuotantoasetus (134/2006)

SFS-EN ISO 19458. Näytteenotto mikrobiologista tutkimusta varten

SFS-EN ISO 8199. Veden laatu. Yleinen ohje mikro-organismien lukumäärien määrittämiseksi viljelymenetelmällä SFS-EN ISO 7899-2. Veden laatu. Suolistoperäisten enterokokkien havaitseminen ja laskeminen. Osa 2:

Kalvosuodatusmenetelmä

Colilert. http://www.idexx.com/resource-library/water/colilert-procedure-en.pdf 